\title{
FENERBAHÇE YANDEX ANA SPONSORLUĞUNUN TARAFTAR DAVRANIŞLARINA ETKISI: BEŞiKTAŞ, FENERBAHÇE ve GALATASARAY TARAFTARLARI ÖRNEĞi
}

Yusuf Bahadır DOĞRU ${ }^{1}$

\begin{abstract}
öz
Markanın hedef kitleleri arasında karşılıklı iletişimi kurup, markaya yönelik farkındalığı arttıran, güveni, sempatiyi ve olumlu imajı oluşturan halkla ilişkilerin, en fazla kullanılan uygulamalarının başında sponsorluk gelmektedir. Sponsorluk içinde en çok kullanılan alanlardan biri de spor sponsorluğudur.

$\mathrm{Bu}$ araştırma; spor sponsorluğu kapsamında değerlendirilen futbol takımları ana sponsorluğunun taraftar davranışları üzerindeki etkisinin belirlenmesi amacıyla gerçekleşmiştir.

Araştırmanın verileri odak grup görüşmesi tekniği kullanılarak toplanmıştır. Amaç doğrultusunda hazırlanan odak grup görüşmesi soruları, "Fenerbahçe Yandex Ana Sponsorluğu" hakkında bilgisi olan ve sponsorluk dersini almış gönüllü İletişim Fakültesi öğrencilerinden on Fenerbahçe ve beş Beşiktaş ve beş Galatasaray taraftarı olmak üzere yirmi kişi ile yapılmıştır. Görüşmeler Fenerbahçe taraftarı ve Beşiktaş, Galatasaray taraftarı olmak üzere iki gruba ayrılmıştır ve her iki grup ile farklı zamanlarda yaklaşık birer saatlik odak grup görüşmesi gerçekleştirilmiştir. Görüşmeler esnasında ses kaydı alınmış olup, ses kaydı deşifre edilerek Microsoft Office Word programına aktarılmıştır. Veriler betimsel analiz yöntemiyle analiz edilmiştir.

Anahtar Kelimler: Fenerbahçe, futbol, ana sponsorluk, tüketici, taraftar

\section{EFFECTS OF THE FANS BEHAVIOR IN THE OFFICIAL SPONSORSHIP OF YANDEX TO \\ FENERBAHÇE: THE EXAMPLES OF FANS OF FENERBAHÇE, GALATASARAY AND \\ BEŞiKTAŞ}

ABSTRACT

By providing a correspondent communication between target markets, sponsorship is the most used practice, which enables confidence, makes a positive relationship between two sides and also raises awareness. İn terms of sponsorship, sport sponsoring is the most used one.

This research was done in order to define the effects of the official sponsors for the football teams on the fans of these team regarding the sport sponsorship.

The outcomes of the research was provided by applying the focused group conversation. The focused group conversation questions which were prepared according to the aim, were asked to those who are the students in the faculty of communication having knowledge about "Yandex Fenerbahçe Official Sponsoring" and having taken the sponsorship lessons beforehand, are twenty people five of whom are fan of Galatasaray,the other five are fan of Beşiktaş and the rest is fan of Fenerbahçe.
\end{abstract}

\footnotetext{
${ }^{1}$ Arș. Gör. Kocaeli Üniversitesi İletişim Fakültesi, yusuf.dogru@kocaeli.edu.tr
} 
The interviews were divided into two groups as fans of Fenerbahçe and fans of Galatasaray and Beşiktaş and with these two groups, focused group conversations were made as one hour and at different times. While meeting, a voice recorder was used and then these Records were transcripted into Microsoft Office Word by deshipering. The data was analyzed with descriptive analysis format.

Key Words: Fenerbahçe, football, official sponsoring, consumer, fans

\section{Giriş}

Günümüzde dünyasının değişen koşullarıyla birlikte markalar hedef kitlelerine ulaşmak, onların gözünde olumlu bir imaj elde edebilmek ve kurumsal hedeflerini gerçekleştirebilmek için birçok yöntem ve teknikten faydalanmaktadırlar. $\mathrm{Bu}$ yöntemlerden birisi de "sponsorluk" faaliyetleridir.

Sponsorluk karşılıksız bir yardım, ismin gizlendiği bir hayırsever bağışı değildir. Sponsorluk mutlaka sponsor olan kurumun adının ekranda, yayında ya da ilgili olayda yer almasını gerektirir. Bununla birlikte kurumun imajı güçlenir, tanıtımı sağlanır, kurum kendi kimliğiyle kamuoyu nezdinde hak ettiği yere oturur. Sponsorluk belirlenmiş amaçlara ulaşmak üzere desteklenen ve destek arayanlar arasında yapılan ve karşılıklı çıkarlara hizmet eden bir iş düzenlemesidir (Kazancı, 2002)

Sponsorluk türlerinin içinde en eski ve en yaygın olan sponsorluk türü spor sponsorluğudur. Her türlü sportif faaliyet spor sponsorluğu kapsamına girebilir. $\mathrm{Bu}$ bakımdan değişik alanlardaki sportif faaliyetler, sponsor olan kurumlara hedef kitlelerine ulaşabilmeleri açısından geniş olanaklar sağlamaktadır. $\mathrm{Bu}$ nedenle markaların spor sponsorluğunu tercih etme nedenlerinin başında, sporun toplum tarafından sevilmesi, buna bağlı olarak medyanın spora, özellikle futbola geniş bir yer ayırması, bu sayede sportif faaliyeti destekleyen sponsorun toplumla rahat bir şekilde bağlantı kurmasını ve bilinirliğinin artmasına olanak sağlamaktadır (Grassinger, 2003: 53-54).

Spor sponsorluğu geniş kitlelere hitap etmesi sayesinde, ürün ve hizmetlerini kısa zamanda bu kitlelere tanıtmak isteyen markalar tarafından özellikle tercih edilmektedir. Çünkü spor, hedef kitleyle iletişim kurma olanağı sağlayan ve hemen hemen bütün dünyada anlaşılan, evrensel bir dilin konuşulduğu bir sponsorluk alanıdır. Bu bağlamda, markalar ulaşmak istedikleri hedef kitlelerine göre ürün ya da 
hizmetlerini tüm toplumlara duyurabilmek adına ulusal, uluslararası ya da yerel bir organizasyonunu hizmet, malzeme ya da mali bakımdan destekleyebilir (Okay, 1998: 68).

Spor sponsorluğu ve sponsorluk literatürüne göre sponsorluk, tüketiciler üzerinde etkiler oluşturmaktadır. Bu etkiler sponsora yönelik tutum, etkinliğe yönelik tutum ve sponsor etkinlik uyumu eksenlerinde gerçekleşmektedir. Firmaların rağbet gösterdiği ve gün geçtikçe de verimliliğini sorguladıkları en büyük sponsorluk alanı olan spor sponsorluğunun bu etkileri, tüketicilerde firmanın ürünlerine yönelik ürünle ilgilenme, ürünü benimseme ve ürün tüketimi anlamında reaksiyonlara sebep olmaktadır (Alay, $2004: 2$ ).

Araştırmanın, esas hedefi tüketici olan Fenerbahçe-Yandex futbol ana sponsorluğunun, kişilerin tüketici davranışları üzerindeki etkisini ortaya çıkarmaktır.

\section{Sponsorluk}

Kelimenin Latince kökenine bakıldığında Spansio başlangıçta dini nitelik taşıdığı sanılan sözle taahhüt şeklini ifade ederdi. Yunanca'da sponsore vaat etmek, söz vermek anlamında kullanılmıştır (Yağız, 2012: 15).

\subsection{Sponsorluk Kavramı}

Sponsorluk kavramını daha iyi anlamak için reklamdan farklı yönlerini düşünmek gerekir. Tüketiciler reklamı genellikle ticari bir iletişim biçimi olarak görürler ve reklamı yapan işletmenin ya da reklamı yapılan ürünün kendi çıkarları için hareket edildiğini düşünürler. Hatta belirli ürünleri/markaları satın almamız için bizi yönlendirdiklerini, ikna etmeye çalıştıklarını ve baskı kurduklarını düşünebilirler. Günümüzde tüketicilerin bir kısmının kafası reklam konusunda kuşkucu olabilir. Oysa tüketiciler sponsorluğun sadece sponsor olan kuruma değil bunun çok daha ötesinde faydaları olduğuna inanırlar. Sponsor firmanın ticari dürtülerinin yani belirli amaçlara ulaşmak için sponsorluk faaliyetinde bulunduğunu bilmelerine rağmen bu iletişim biçimine genel bir iyi niyet çerçevesinde yaklaşırlar (Öztürk, 2013: 4).

Sponsorluk kavramı belirli bir ticari amacı barındırır. $\mathrm{Bu}$ anlamda 
hayırseverlik ile karşılaştırılmaması gereklidir. Kişiler, işletmeler ve diğer kurumlar herhangi bir ticari amaç gütmeden ya da herhangi bir karşılık beklemeden ihtiyaç duyan kişilere ya da organizasyonlara parasal destek ya da donanım desteği sağlayabilir. Söz gelişi spor tutkusu da olan hayırsever bir işadamının bir meslek yüksekokuluna spor salonu yaptırması ya da ulusal bir spor organizasyonuna katılacak olan maddi olanakları sınırlı sporculara parasal destek vermesi sponsorluk kapsamında değil, hayırseverlik kapsamında düşünülmelidir. Bu durumda işadamının yaptığı destek aracılığı ile medyada yer almak, işletmesine/ürünlerine yönelik olumlu tutum oluşturmak, imajını geliştirmek gibi bir amacı yoktur. İşadamı bu durumu açıklamadıkça kamuoyunun haberi olmayacaktır. Dolayısıyla sponsorluk kavramını işletmelerin herhangi bir ticari kazanç beklentisi olmadan finansal katkıda bulundukları yardım, hibe ve bağışlardan ayırmak gereklidir. Bu tür parasal ve benzeri katkılar işletmelerin sosyal sorumlulukları bağlamında düşünülmelidir. Sponsorluk ise hem toplumsal fayda sağlayan hem de işletmelerin kendi çıkarları doğrultusunda ticari bir yarar sağlama gücü olan bir araçtır (Öztürk, 1992: 18) .

Genellikle marka imajına olan katkısı, kurum kimliğinin oluşturulması ve yerleştirilmesi kurum itibarına etkisi gibi unsurlar sponsorluk faaliyetinin halkla ilişkiler yöntemi olarak değerlendirilmesine neden olmaktadır. Diğer açıdan değerlendirildiğinde sponsorluk, reklam ve pazarlama amaçları arasında da ilişki söz konusudur. Bu sebeple sponsorluğun gerek kurumsal, gerekse pazarlama amaçlarıyla etkileşimi onu iletişim stratejilerinin temel taşı haline getirmektedir (Peltekoğlu, 2012: 366).

Sponsorluk firmalara, çeşitli etkinlik ve olaylara destek sağlayarak hedef kitleleriyle bir araya gelme, samimi bir ortam sunma olanağı sağlamaktadır. Marka farkındalığı oluşturma ve kamuoyu gözünde olumlu bir algı ve imaj oluşturmada oldukça faydalıdır. $\mathrm{Bu}$ nedenle birçok firma sponsorluk etkinliklerine iletişim ve pazarlama bütçelerinden daha fazla pay ayırmaya, üzerinde daha fazla durmaya başlamıştır (Odabaşı ve Oyman, 2006: 343).

Akyürek’e göre, sponsorluk kurumsal ya da pazarlama amaçlarına yönelik, doğrudan medya kanallarını satın almadan gerçekleştirilen olay ya da nedenler için yapılan ticari bir yatırımdır. Yine Akyürek'in bir başka tanımına göre sponsorluk, 
belirli amaçlara ulaşmak için destekleyen ve desteklenen arasında yapılan ve karşılıklı çıkarlar sağlayan iş düzenlemesidir (Akyürek, 1998: 6-7).

Sandler ve Shani’ye (1989: 10) göre sponsorluk; bir kuruluşun, olay ya da organizasyon için doğrudan bir ortaklık karşılığında belirlenen kaynakların (para, insan, donanım) sağlanmasıdır.

Sponsorluk, bütün dünyada çağdaş uygulamaları ile önemli bir halkla ilişkiler yönetimidir. Sponsorluk uygulamalarında tek başına, kuralları olan ve ilkeleri olan bir yönetim biçimi değildir. Sponsorluk, halkla ilişkiler içerisinde yer alan teknikler bütünüdür. Bu nedenle sponsorluk " kuruluşun kendi sorumluluk alanı dışında kalan planlı bir olay ya da etkinliğe kar ya da tanıtım amacıyla maddi destek vermesi” şeklinde tanımlanabilir. Ancak sponsorluk karşılıksız bir yardım aracı değildir. Sponsorluk uygulamalarının da sponsor olan kurumun isminin, markasının, ambleminin, logosunun ekranda yayında ya da ilgili olayda yer almasını gerektirmektedir (Kazanc1, 2007: 371).

$\mathrm{Bu}$ tanımlara göre sponsorluk, kurumsal amaçlara ulaşmak için spor, sanat/kültür ve sosyal faaliyet alanlarında, kişi ve organizasyonların para, araç/gereç ya da hizmet ile desteklenmesi ve bu aktivitelerin planlaması, organizasyonun yürütülmesi ve kontrolüdür. Bu da sponsorluğu mesenlikten ayıran en önemli üç özelliği ortaya çıkartmaktadır. Bunlar;

- Sponsor tüm yaptıklarına sponsor olduğu markanın da karşılık vermesini bekler,

- $\quad$ Sponsorluk faaliyetlere para, araç/gereç kazandırabileceği gibi hizmet olarak da geri dönebilir,

- Sponsor verdiği desteğin, panolarda firma logosunun yer almas1, kıyafetlerin üzerine baskı vb. yöntemlerle medyaya açıklanmasını ister.

Bunun sonucunda sponsorluk uygulamalarıyla sanata, spora, bilime verilen destek, bir yandan o disiplinlerin gelişimine katkıda bulunurken, diğer taraftan sporcu, sanatçı, bilim adamı, ya da araştırmacıyı gereksinim duyduğu olanağa da kavuşturmaktadır (Brückner 1996'dan aktaran Peltekoğlu, 2012: 370). 


\subsection{Spor Sponsorluğu Kavramı}

Spor sadece seyirlik bir olay olmaktan çıkmış günümüzde endüstrileşerek bir sanayi koluna dönüşmüştür. Dünya Kupaları, Olimpiyatlar, Avrupa Kupaları gibi önemli spor olaylarının canlı yayınları, yazılı ve görsel medyada önemli yer ve zaman kaplamaları, sporun endüstrileşme sürecine katkı sağlamıştır (Oğuz, 2005: 201-202). Günümüzde spor ve sponsorluk kavramları da birbirlerinden ayr1 düşünülemez hâle gelmiştir. Ancak sponsorluğun ne olduğu konusunda herkesin farklı fikirleri olabilir ve hatta sponsorluk diğer başka kavramlarla karıştırılabilir (Öztürk, 2013: 3).

Spor sponsorluğu genel sponsorluk tanımına göre sadece spor alanı ele alınarak tanımlanır. Bir markanın veya sponsorun önceden belirlemiş olduğu hedeflere ulaşabilmek amacıyla beklediği çeşitli faydalar karşılığında bireyin, bir otoritenin, bir kulübün veya organizasyonun faaliyetlerini devam ettirebilmesi için para, donanım vb. kaynakları sağlaması şeklinde bir tanım yapılabilir veya daha özetle bir kuruluşla sporcu, takım veya spor faaliyeti arasında karş1lıklı faydalar elde etmek amacıyla taraflar arasında yapılan ticari bir anlaşma şeklinde tanımlanabilir (Okay, 2002: 49).

Buna göre pazarlama stratejilerinde belirlenen amaç ve hedeflerine ulaşmada yararlanılabilecek en etkili tutundurma araçlarından biri olan spor sponsorluğu şirketlerin en fazla tercih ettiği sponsorluk türüdür (Covell, 2008: 125).

Spor sponsorluğunun en fazla rağbet gören sponsorluk türü olmasının başlıca nedenlerinden birisi de sporun bir evrensel bir dilinin olmasından kaynaklanmaktadır. İçinde bulunduğumuz yüzyıl bir iletişim çağı, televizyon kanalları her türlü spor organizasyonunu yayın haklarını satın alarak kendi ülkelerinde dünya ile aynı anda yayınlayabiliyorlar. Bir futbol müsabakasını düşündüğünüzde kurallar Fransa'da oynayan futbolcular için de aynı, Türkiye'de oynayan futbolcular için de yine aynı. Bu iki ülke takımları karşılıklı maç yaptıklarında ise aynı kurallar üzerinden oynamakta ve başta stattaki seyirciler olmak üzere ekranları başından milyonlarca hatta milyarlarca insan aynı anda bu müsabakayı izleme imkanı bulmaktadırlar (Çavuşoğlu, 2011: 95). 
Spor sponsorluğu, günümüzde dünyadaki tüm şirketlerin pazarlama stratejileri içerisinde kendine yer bulmaktadır. Spor sponsorluğuna yatırılan miktarların gün geçtikçe arttığı ve sonraki süreçte de artacağını çeşitli araştırmalar ortaya koymaktadır (Copeland vd., 1996: 32).

Spor sponsorluğuna yapılan harcamaların artması, bu alana olan ilgiliyi arttırmaktadır. Spor sponsorluğu gün geçtikçe gelişimine devam ederek markaların ilgisini çekmeye devam edebilecek güce sahip olduğu düşünülmektedir. Hedef kitle ile farklı yollardan iletişim kurmak, marka imajlarını geliştirmek, sempati kazanmak ve farkındalığı arttırmayı arzulayan markalar, spor sponsorluğunu değerlendirerek olumlu geri dönüşler almaktadırlar. Sponsorluğun yararlı olabilmesi, her şeyden önce kavramın ve sponsorluk yönetim sürecinin doğru ve yerinde adımlarla uygulanmasına bağlıdır. Bu bakımdan sponsorluk kavramının tüm yönleriyle araştırılması gerekmektedir. Sponsorluk faaliyetine dahil olan ve dahil olmayı düşünen markalar, kavramı bir süreç içerisinde değerlendirerek ele almak durumundadırlar. Sponsorlukta sürece bağlı kalınarak; sponsorluk amaçlarının belirlenmesi, amaçların etkin kullanımı, uygun duyurumun sağlanması ve etkinliğin ölçümü ve değerlendirilmesi büyük önem taşımaktadır (Karademir vd., 2010: 86).

\subsection{Ana Sponsorluk}

Günümüzde gerçekleştirilen spor organizasyonlarının büyüklüğü ve uluslararası boyutu düşünüldügünnde özel sponsorların bu organizasyonların maliyetini tek başına karşılayamayacağı açıktır. Dolayısıyla pek çok spor olayının gerçekleşebilmesi için spor olayının masraflarını paylaşacak birden fazla sponsora gereksinim duyulur. Çok sponsor olması durumunda sponsorluk paketini yapılandırmak ve böylece sponsorların farklı finansal katkılarla destek verebilmeleri mümkün olur. Pek çok sponsor olması durumunda bile bir ana sponsor genellikle ayrıcalıklı haklara sahiptir. Bir ana sponsor isminin spor olayının adının içinde yer almasını ve adının basında ve televizyonda olay ile bağlantılı olarak bahsedilmesini müzakere edebilir. Bu ana sponsora ayrıcalıklı imaj kazandırabilir. Hatta izleyiciler ve spor olayının katılımcıları takımı ya da spor olayını sponsorun ya da ürünün ismiyle bağdaştırmaya başlarlar. Ana sponsorluğun bir avantajı ise ana sponsor özel sponsorlukla karşılaştırıldığında spor olayının finansal risklerini diğer sponsorlarla 
paylaşabilmesidir. En önemli problem ana sponsorun programdan çıkması durumunda spor olayını devam ettirebilecek finansal desteğin önemli oranda azalmasıdır. Dolayısıyla ana sponsorun spor olayı ile ne kadar çok bütünleşmesi sağlanırsa sponsorluk anlaşmasından çıkması da o kadar zorlaşacaktır (Öztürk, 2013: 11).

\subsection{Futbol ve Sponsorluk Ilişkisi}

Pazarlama iletişimi çalışmaları içerisinde sponsorluk faaliyetleri önemli bir yere sahiptir. Sponsorluğun temel amacı belirlenen hedef kitleye yönelik işletmenin sunmakta olduğu ürün ve hizmetlere ilişkin olumlu tanıtım gerçekleştirmektir. Sponsorluk çalışmalarının büyük bir kısmı sponsorun kurumsal imajının hedef kitleye doğru şekilde yansıtılmasını sağlamaktır. Futbol liglerinde takımların gelirlerinin büyük bir bölümü farklı markalarla imzalanan sponsorluk anlaşmalarından sağlanmaktadır (Enginkaya, 2014: 146).

Futbol sponsorluğu markalar tarafından önemli bir pazarlama stratejisi haline gelmiştir. Markalar futbol sponsorluğunu, kitle izleyicilerle iletişim kurmak ve rekabet avantajı elde etmek için kullanmaktadırlar (Chadwick ve Thwaites, 2004).

Spor sponsorluğu gün geçtikçe daha popüler hale gelmekte, büyük şirketler tarafından marka değeri oluşturmada ve pazarda rekabetçi avantaj sağlamada önemli bir pazarlama ve iletişim stratejisi olarak kullanılmaktadır. Buna bağlı olarak sponsorluk faaliyetleri kulüplere büyük bir gelir kaynağı sağlamada önemli bir pazarlama aracı olarak görülmektedir. (Biscaia vd., 2013: 289).

Spor müsabakalarında sponsor markalara ait görsellerin kullanımı tüketicilerin/taraftarların dikkatini çekmektedir. Takım oyuncularının formalarında veya taraftarı oldukları takımın stadyumunda sponsor marka isimleri ile karşılaşan taraftarlar ilgili markalarla psikolojik bağlar kurabilmektedirler. Özellikle futbol müsabakalarının atmosferi, taraftarın hissettiği heyecan, taraftarın takımla özdeşleşme derecesi sponsor markanın tanıtımını olumlu yönlerden etkileyebilmektedir. Oluşturulan olumlu çevrenin, taraftarların algı ve tutumlarını doğrudan etkileyeceği beklenmektedir. Duygusal açıdan yoğun bir ortamda sunulan iletişim mesajlarının farklı ortamlara kıyasla daha fazla hafızada kalması da beklenen bir diğer unsurdur (Bennet, 1999: 291-293). Bu özellikler nedeniyle farklı alanlarda 
faaliyet göstermekte olan markalar futbol liginde mücadele etmekte olan takımların sponsoru olma konusunda istekli davranmaktadırlar (Enginkaya, 2014: 146).

Günümüzde üst düzey profesyonel bir futbol kulübünün, gelirlerini arttırmaya yönelik şirketlerle yaptığı anlaşmalar, bir reklam anlaşmasından çok, bir sponsorluk anlaşmasıdır. Bu anlaşmaların, sponsorluk özelliği taşımasının bazı nedenleri vardır. Bunlardan bir tanesi, bu anlaşmaların, en az 2-3 yıl gibi uzun süreli olmasıdır. Halbuki, reklam anlaşmaları daha kısa süreli olmaktadır. Sponsorluk anlaşmalarını reklam anlaşmalarından ayıran bir başka özellik, spor dünyasının baş aktörlerinin, özellikle de alanlarının önde gelenlerinin, her sektörden tek bir şirket ile anlaşmasıdır. Finans sektöründen bir banka ile anlaşma yapılmışsa, ikinci bir banka ile sponsorluk sözleşmesi yapıl(a)mamaktadır. Bu teorik yaklaşımın en güncel örneklerinden biri, FC Barcelona-Türk Hava Yolları (THY) arasındaki sponsorluk anlaşmasıdır. İspanyol kulübü THY ile olan sponsorluk sözleşmesinin 2013 yılı içerisinde bitmesinden sonra, anlaşmanın yenilenmeyeceğini açıklamıştır. Sözleşmenin yenilenmemesinin nedeni ise Barcelona futbol kulübünün Katar Havayolları ile daha cazip bir sponsorluk anlaşması yapmasıdır. Barcelona'nın böyle bir anlaşması Türk Hava Yolları ile sponsorluk anlaşması devam ederken hayata geçirme şansı yoktur. Halbuki bir reklam anlaşması olsaydı anlaşmayı istediği zaman devreye sokabilirdi. Ne var ki sponsorluk uygulamaları bu tip uygulamalara izin vermemektedir (Çetin, 2014: 213).

Türkiye'de yapılan futbol takımları ana sponsorlukları başarılı örnekler sunmaktadır. Örneğin, Vodafone ve Beşiktaş'ın yapmış olduğu ana sponsorluk anlaşmasında, kulüp ve sponsor olan firma başarılı iletişim çalışmaları yürütmektedir. Vodafone ve Beşiktaş yeni medyayı aktif bir şekilde kullanarak sempati oluşturmakta ve farkındalık yaratmaktadır. Aynı zamanda sponsor olan marka da taraftarın gözünde imajını tazelemektedir ve sempati kazanmaktadır.

Şekil.1 Beşiktaş ve Vodafone Arasındaki Twitter Diyaloğu 


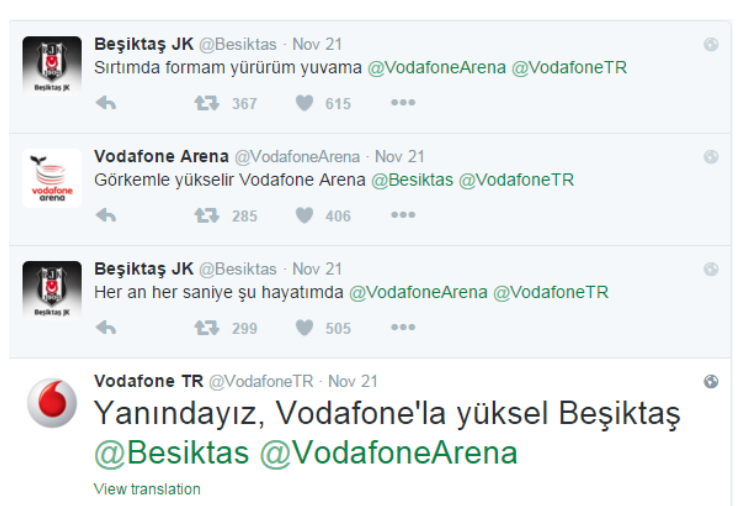

Beşiktaş Jimnastik Kulübü, Vodafone Arena ve Vodafone Türkiye, Twitter hesaplarının gönderdikleri bu paylaşımlar, taraftar arasında oldukça popüler olmuştur ve birçok olumlu cevaplar verilmiş ve retweetler yapılmıştır.

\subsection{Spor Sponsorluğu Bağlamında Tüketici/Taraftar Davranışları}

Tüketicinin sponsorluğa bakış açısındaki iyi niyeti, yalnızca sponsorluğu reklamdan ayırt etmekle kalmamaktadır. Sponsorluk ile bilinirlik, farkındalık, marka imajı, hedef kitlenin zihninde marka konumlandırılması amaçlanır. Sponsorluğa karşı olumlu bir tutum ve davranış sergileyen tüketicilerin/taraftarların/izleyicilerin, sponsor markalara karşı da dolaylı yoldan olumlu bir tutum oluşturduğu görülmektedir (Gümüş ve Erdem, 2014: 5)

Olimpiyat oyunları ile ilgili yapılan araştırmaya göre; sponsorluk çıktıları tüketicinin zihnindeki olumlu ve olumsuz inançlardan oluşmaktadır. Örneğin, bir üniversite stadyumunun isim haklarını satın alan bir sponsor, böyle bir ilişki kurarak taraftarların stadyuma yüklediği anlamın kendi markasına transfer olmasını bekler. Buna ek olarak böyle bir sponsorlukta sağlanan finansal destekten dolayı taraftarlar, sponsor olana olumlu bir tutum oluşturması beklenir. Taraftarlar, sponsor olan markanın sağladığı finansal desteğin spor karşılaşması için ciddi bir gelir kaynağı olduğunu düşünebilir. Yine bu durumda sponsor olana iyi bir tutumu yapılandırır. Bunun aksine, birey sponsorun bu spor karşılaşmasına adını vererek durumu fazlasıyla ticarileştirdiğini de düşünebilir. Bu durum sponsor olana karşı olumsuz bir tutuma neden olabilir. Tüm bu inançların hepsi birden tutumları oluşturur. $\mathrm{Bu}$ durumda tüketicinin olumlu inançları olumsuzlardan daha fazlaysa, olumlu bir tutum 
oluşur. Aksi halde, oluşan olumsuz tutumlar tüketicinin sponsoru destekleyecek olan satın alma davranışından uzaklaşmasına yol açar (Lee vd., 1997).

Sponsorluk faaliyetleriyle iletilmek istenilen mesajın tüketicilere doğrudan transfer edilmesi kolay değildir. Bu nedenle tüketicilerin sponsor marka hakkında en azından temel bilgisinin olması, söz konusu mesajın iletilmesi ve marka imajının olumlu yönde etkilenmesi açısından önemlidir. Tüketicilerin belirli bir bilgi düzeyine sahip olması, kuruluşlara, sponsorlukla geliştirilmiş olan marka bilgisinin tüketicilerde değer yaratacak şekilde kullanılması olanağını sağlamaktadır (Roy ve Cornwell, 2003; Grohs vd., 2004).

Chen ve Zhang, Spor Sponsorluğu İnanç-Tutum-Hiyerarşisini açıklarken, spor sponsorluğu anlaşmasını gerçekleştiren markaya karşı olumlu yöndeki inançlar, sponsor olan markaya duyulan olumlu tutumlara dönüşür, olumlu tutumlar ise markanın ürünlerini satın almaya ya da hizmetlerini kullanmaya yönelik davranışlara dönüşmektedir (Chen ve Zhang, 2011: 103). Örneğin; Fenerbahçe- Yandex ana sponsorluk anlaşması sonucunda, Yandex'e karşı hissedilen olumlu inanç ve tutumlar, Yandex hizmetini kullanmaya yönelik davranışlara dönüşebilmektedir.

Şekil 2. Spor Sponsorluğu İnanç- Tutum- Davranış Hiyerarşisi

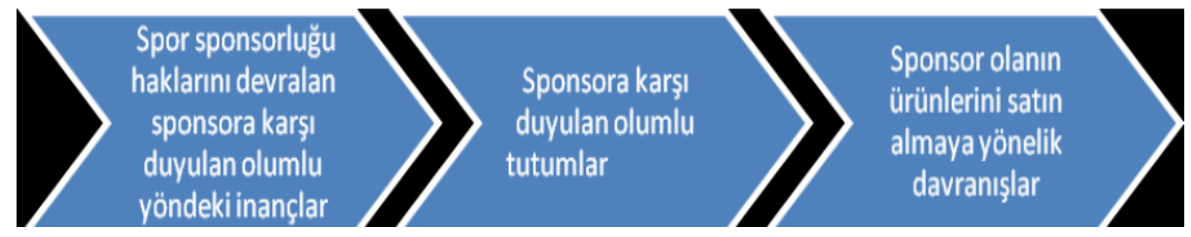

Kaynak: (Chen ve Zhang, 2011: 103)

Futbol kulüpleri ile sponsorluk anlaşması yaparak yatırım yapan sponsorlar açısından futbol taraftarı arasındaki sponsorluk bilincini değerlendirmek ve değerini anlamak önemlidir. Ek olarak bu bilgi gelecekteki sponsorluk görüşmeleri için çok önemlidir. Eğer taraftarlar takımlarına sponsor olan markalarının farkındaysa, marka bilinci oluşmuş, marka farkındalığı sağlanmış ise bu potansiyel sponsorlar için ilgi çekici bir yatırım aracı haline dönüşebilmektedir (Biscaia vd., 2014: 10).

\subsection{Fenerbahçe Futbol Kulübü'nün Yandex Ana Sponsorluk Anlaşması}


Fenerbahçe futbol kulübünü ana sponsorluk için Yandex'le anlaşılmasını Kamuoyu Aydınlatma Platformu'na, 18 Ağustos 2015 tarihinde yapılan açıklama ile duyurmuştu. Açıklamada; “Takımımızın tüm ulusal futbol lig maçlarındaki forma göğüs reklamı için Yandex firması ile anlaşılmıştır. Anlaşmaya göre www.fbyandex.com.tr arama sayfasından yapılan arama sayısı performansına göre gelir sağlanacaktır. Sözleşmenin süresi azami 3 yıl olup ara dönemlerde sağlanan performansa göre gözden geçirilecektir.” bilgisi yer almaktadır (www.kap.gov.tr).

Yandex, Türkiye'deki kullanıcılar ve Türkiye hakkında bilgi arayan herkes için geliştirilmiş, kullanıcılarına İnternet'te aramanın yanı sıra haberler, e-posta gibi birçok farklı İnternet servisi sunan bir arama motoru ve web bilgi portalıdır. ComScore verilerine göre bütün dünyada 100 milyondan fazla kullanıcı tarafindan tercih edilerek dünyanın önde gelen arama motorlarından biri olan Yandex, kuruluşundan bu yana 10 yılı aşkın bir süredir \%60'a yakın bir pazar payıyla Rusya piyasasındaki lider konumunu korumaktadır. Birkaç yıl önce Ukrayna, Beyaz Rusya ve Kazakistan için de özel portallarını açan Yandex, servislerini başka dillere çevirmekle kalmayıp çalıştığı her ülke için gerçek birer yerel ürün sunmak üzere çaba göstermektedir (www.sirket.yandex.com.tr).

Ayrıca Fenerbahçe kulübü resmi web sitesinde, anlaşmanın detayları da yer almıştır. Fenerbahçe Yandex tarayıcısından yapılan aramalarda kulübün ne kadar gelir elde edeceği, hangi şartlarda bu geliri elde edeceği ayrıntılı bir şsekilde aktarılmıştır. Örneğin; yılda yapılan 1200 aramanın kulübe 36 \$ kazandıracağı bilgisi resmi web sayfasında yer almaktadır.

\section{Fenerbahçe Yandex Ana Sponsorluğunun Taraftar Davranışlarına Etkisi'nin İncelenmesi}

\subsection{Araştırmanın Konusu}

Yandex'in, Fenerbahçe Futbol Kulübü ile imzalamış olduğu ana sponsorluk anlaşması kapsamında; Fenerbahçe, Beşiktaş ve Galatasaray taraftarlarının, Fenerbahçe ve Yandex markasına yönelik davranış değişikliklerinin ve tepkilerinin incelenmesidir.

\subsection{Araştırmanın Evren ve Örneklemi}


Araştırmanın evrenini Kocaeli Üniversitesi İletişim Fakültesi öğrencileri oluşturmaktadır. Örneklem seçiminde, amaçlı örneklem yöntemi kullanılmıştır. Bu kapsamda, futbola ilgi duyan ve Fenerbahçe Yandex Ana Sponsorluk anlaşması hakkında bilgisi olan gönüllü katılımcılar örneklem olarak seçilmiştir. Evrenin seçiminde futbola en çok ilgi duyan yaş kitlesinin 18-25 yaş olmaš ${ }^{2}$, bu kitlenin üniversite öğrencilerinden oluşması ve "Sponsorluk" dersini alarak, sponsorluk kavramından haberdar olan öğrenciler arasından seçilmesi etkili olmuştur.

\subsection{Araştırmanın Metodolojisi}

Araştırmada, nitel araştırma yöntemlerinden biri olan odak grup görüşmesi kullanılmıştır. Odak grup görüşmeleri, küçük katılımcı gruplarıyla yönlendirici (moderatör) bir kişi eşliğinde yürütülen ve katılımcıların tümünü ilgilendiren bir konuda, onların görüşlerini belirlemeyi amaçlayan görüşmelerdir. Odak grup görüşmeleri, genellikle bir ürün, hizmet ya da olanağın kullanıcılar tarafından nasıl algılandığını ortaya çıkarmak için gerçekleştirilmektedir (İftar, 2004: 1). Bu amaçla; incelenecek konu hakkında görüş bildirecek bireylerden odak gruplar oluşturulmaktadır. Her bir odak grup yönlendirici kişi eşliğinde ayrı ayrı toplanmakta ve gruptaki katılımcılar araştırma konusuyla ilgili görüşlerini bildirmektedirler (Salı, 2012: 122).

Odak grup görüşmelerinin yararı; odak grup görüşmelerinin araştırmacılara seçilen araştırma konusu ile ilgili derinlemesine bilgi edinme olanağını tanıması, anket çalışmalarına kıyasla daha az sayıda kişiye ulaşılmasına rağmen, katılımcıların belli bir konudaki tutum ve görüşlerini o kişiye özgü ifade ve tanımlamalarla, daha geniş bir yelpazede sunmasıdır (Tozkoparan ve Vatansever, 2011: 97).

Araştırmanın bulguları betimsel çözümleme yöntemiyle çözümlenmiştir. Bu yaklaşımda elde edilen veriler, belirlenen temalara göre sınıflandırılır ve yorumlanır. $\mathrm{Bu}$ temalar, araştırma sorularıyla, görüşme ve gözlem sürecinde kullanılan sorularla oluşturulabilir. Burada amaç, elde edilen bulguları belirli bir sistematik yaklaşımla düzenleyerek yorumlamak ve okuyucuya sunmaktır. Öncelikle, verilerin araştırma

\footnotetext{
${ }^{2}$ Üç büyüklerin taraftar profili www.efordergi.com/index.php/2015/01/01/turkiyenin-uc-buyuklerintaraftar-profili/
} 
sorularına ilişkin olarak neleri belirttiği ya da hangi sonuçları ortaya koyduğu betimlenir. Daha sonra bu betimlemeler açıklanır ve neden-sonuç ilişkileri incelenerek genel bir çerçevede yorumlanır (Yıldırım ve Şimşek, 2004: 171-172).

\subsection{Araştırmanın Gerçekleştirilmesi, Veri Toplama ve Analiz Yöntemi}

Görüşmeler, 2015 yılının Kasım ayında gerçekleştirilmiştir. Katılımcılara, görüşme gününden yaklaşık bir hafta önce, görüşmenin yapılacağı saat ve yer hakkında bilgi verilmiştir. Araştırmaya on Fenerbahçe taraftarı ile beş Beşiktaş ve beş Galatasaray taraftarı katılmıştır. Araştırmaya ilk olarak on Fenerbahçe taraftarı alınmıştır ve yaklaşık olarak bir saat odak grup görüşmesi gerçekleştirilmiştir. Ardından bir sonraki gün, Beşiktaş ve Galatasaray taraftarıyla odak grup görüşmesi gerçekleştirilmiştir.

Katılımcıların, odanın fiziksel olanakları doğrultusunda $U$ düzeninde oturmaları sağlanmıştır. Görüşmede, bir moderatör hazır bulunmuştur. Görüşme süresince katılımcılara müdahalede bulunulmamış ve derinlemesine bilgi edinme olanağı sağlanmıştır. Moderatör, görüşme yönergesi doğrultusunda katılımcılara sırayla soruları yöneltmiştir. Ayrıca katılımcılardan önceden izin alınarak konuşmalar ses kayıt cihazıyla kayıt edilmiş ve konuşmalar not edilmiştir. Yaklaşık bir saat süren görüşme sonunda ses kayıt cihazı yoluyla kaydedilmiş olan sözel veri dikkatli biçimde çözülmüş ve birebir yazıya dönüştürülmüş, tutulan notlar ile karşılaştırıldıktan sonra değerlendirilme aşamasına geçilmiştir.

Araştırmanın çözümlenmesinde betimsel çözümleme yöntemi kullanılmıştır. Araştırmada görüşme soruları temel alınarak tema kabul edilmiş ve araştırmaya katılanların görüşme sorularına verdikleri yanıtlardan, alt temalar oluşturularak sunulmuştur. Birebir alıntı olarak kullanılabileceği düşünülen cümleler belirlenmiş ve gerekli görüldüğü durumlarda bulgular bölümünde birebir alıntı olarak yer almıştır. Ayrıca bulguların yorumlanması Fenerbahçe taraftarı ve Beşiktaş ile Galatasaray taraftarı olmak üzere iki kategoriye ayrılıp değerlendirilmiştir ve iki kategori arasında karşıllaştırma yapılmıştır.

\subsection{Araştırmanın Amacı ve Önemi}


Araştırmanın amacı Fenerbahçe futbol kulübüne ana sponsor olan Yandex’in, Fenerbahçe taraftarı ve Beşiktaş ile Galatasaray futbol takımlarının taraftar davranışları üzerindeki etkisinin incelenmesidir. Bir diğer amacı ise, esas hedefi tüketici olan spor sponsorluğu yapan markaların, spora en çok ilgi duyan yaş kitlesi içerisinde yer alan üniversite öğrencileri üzerindeki etkisini ortaya koymaktır. Fenerbahçe-Yandex ana sponsorluk anlaşması taraftar odaklı olmasından dolayı, ana sponsorluğun taraftarlar açısından algılanış biçiminin de önemli bir unsur olduğu düşünülmektedir.

$\mathrm{Bu}$ amaçla hazırlanan çalışma, taraftar pozisyonunda bulunan ve bu nedenle sponsor markaların hedef kitlesi içerisinde yer alan üniversite öğrencilerinin, hem sponsorlukla ilgili davranışlarının ortaya konulması hem de sponsor firmaların bu görüşler doğrultusunda kendi iletişim ve pazarlama stratejilerini geliştirmede ve yönetmede katkı sağlamaları düşünülmüştür.

\subsection{Araştırmanın Hipotezleri}

-Fenerbahçe taraftarı Yandex ile yapılan ana sponsorluk anlaşmasını başarılı bulmaktadır ve vaat edilenlerin gerçekleşeceğine inanmaktadır.

-Fenerbahçe taraftarının futbola olan ilgi düzeyine göre, Fenerbahçe-Yandex tarayıcısını kullanım oranı değişmektedir.

-Fenerbahçe taraftarının Yandex'e karşı olan sempatisi ve bilinirliği artmıştır. Yandex sponsorluğu Fenerbahçe taraftarı üzerinde farkındalık oluşturmuştur.

-Beşiktaş ve Galatasaray taraftarı, Yandex Fenerbahçe'ye ana sponsor olduktan sonra markaya karşı olumsuz bir tutum geliştirmişlerdir.

-Beşiktaş ve Galatasaray taraftarı, Yandex Fenerbahçe'ye sponsor olduktan sonra markanın ürün ve hizmetlerini kullanmayı bırakmışlardır.

-Beşiktaş ve Galatasaray taraftarı Yandex'in bilinirliğinin ve farkındalığının arttığını düşünmektedir.

\section{Bulgular}


Katılımcılar ile yapılan odak grup görüşmesi sonucunda elde edilen veriler, görüşmede sorulan sorulara göre sınıflandırılarak tema olarak kabul edilmiştir. Ayrıca katılımcıların izinleri alınarak alıntılarda isimleri kodlanarak kullanılmıştır.

\subsection{Ana Sponsorluk Kavramı}

Görüşmede sorulan ilk soru, araştırmaya katılan Fenerbahçe taraftarlarının "ana sponsorluk" kavramını nasıl tanımladıklarını ortaya çıkarmayı amaçlamaktadır. Katılımcılar ana sponsorluğu, "maddi yönden öne çıkan, en çok maddi desteği veren sponsorluk" olarak tanımlamışlardır. Ana sponsorluk tanımlarına ilişkin bazı katılımcıların görüşleri şöyledir:

“Bir kuruma en büyük maddi desteği veren sponsordur” (M.)

"Diğer sponsorlara göre ön plana çıkan ve en çok katkıyı sağlayan sponsorluk türüdür”(B.)

Araştırmaya katılan Beşiktaş ve Galatasaray taraftarlarına ana sponsorluk kavramını nasıl tanımladıkları sorulduğunda, Fenerbahçe taraftarına benzer şekilde cevaplar verildiği görülmüştür. Taraftarlar ana sponsorluğu, "maddi yönden en çok kazancı olan, en büyük paya sahip sponsorluk" olarak tanımlamışlardır.

\subsection{Katılımcıların Fenerbahçe Yandex Ana Sponsorluk Anlaşmasını Öğrenme}

\section{Durumları}

Görüşmeye katılan Fenerbahçe taraftarına, Fenerbahçe Yandex Ana Sponsorluk anlaşmasını nereden duydukları, nasıl haberdar oldukları sorulduğunda, katılımcilardan altısı televizyonda yayınlanan program/reklam vasitasıyla haberdar olduklarını söylemişlerdir. Diğer katılımcılar ise, internette yer alan reklamlardan ve sosyal medya paylaşımlarından haberdar olduklarını söylemişlerdir. Beşiktaş ve Galatasaray taraftarı da benzer doğrultuda yanıtlar vererek ana sponsorluk anlaşmasını "televizyondan öğrendik" yanıtını vermişlerdir. Buradan yola çıkarak televizyon reklamlarının ve haberlerinin, tanıtımda ve haber almada etkili bir kaynak olduğu düşünülebilir. 
3.3. Katılımcıların, Fenerbahçe-Yandex Ana Sponsorluk Anlaşması ile ilgili ilk İzlenimleri

Görüşmeye katılan Fenerbahçe taraftarlarına, Fenerbahçe-Yandex Ana Sponsorluk anlaşması ile ilgili ilk izlenimleri sorulduğunda, katılımcıların tamamı Yandex'in Fenerbahçe kulübü sayesinde geniş hedef kitlelere ulaştığını ve reklamını yaptığını vurgulamışlardır. Bu konuya ilişkin bazı katılımcıların görüşleri şöyledir:

"Yandex'in Fenerbahçe'ye ana sponsor olduğunu duyunca ilk izlenimim, Yandex'in Fenerbahçe'nin potansiyelini kullanarak piyasada yer edinme çabası içinde olduğu aklıma geldi” (O.)

“Yandex Rus şirketi olarak Google 'un Türkiye pazarındaki gücünü kırmak olduğunu, bunu yaparken Fenerbahçe'nin taraftar sayısının çok olması ve tutkulu bir taraftarının olmasından dolayı, Fenerbahçe’yi seçtiğini düşündüm” (B.)

Görüşmeye katılan Beşiktaş ve Galatasaray taraftarlarına, ana sponsorluk anlaşması ile ilgili ilk izlenimleri sorulduğunda, katılımcıların tamamına yakını Fenerbahçe adına karlı bir anlaşma olduğunu veya olabileceğini vurgulamışlardır. Bu konuya ilişkin bazı katılımcıların görüşleri şöyledir:

"Fenerbahçe adına başarılı bir anlaşmasıdır, Fenerbahçe'ye iyi geliri olacaktır"(E.)

“Gerçekten büyük bir sponsorluk anlaşması, getirisi çok fazla olabilir"'(İsmail)

“Kıskandiğım bir anlaşma ilk izlenimlerim olumlu”(EM.)

\subsection{Katılımcıların, Yandex Ana Sponsorluk Anlaşmasının Yandex ve Fenerbahçe Kulübüne Katkıları Konusundaki Görüşleri}

Görüşmeye katılan Fenerbahçe taraftarlarına, ana sponsorluk anlaşmasının Yandex ve Fenerbahçe kulübüne katkıları sorulduğunda, katılımcıların tamamı ana sponsorluk anlaşmasının Fenerbahçe'ye maddi kazanç sağladığını, Yandex'e ise farkındalık kazandırdığını ifade etmişlerdir. Ayrıca, Fenerbahçe taraftarlarının Yandex'e karşı olan sempatisinin arttığını ve Türkiye pazarında payının 
artabileceğini vurgulamışlardır. Bu konuya ilişkin bazı katılımcıların görüşleri şöyledir:

“Ana sponsorluk anlaşması Yandex'e farkındalık ve sempati kazandırmıştır. Yandex Türkiye piyasasındaki ulaşabileceği hedef kitlesini arttırmıştır. ” (B)

“...ana sponsorluk Fenerbahçe’ye maddi olarak katkl sağladı, Yandex'e ise daha fazla tanınırlık kattı, Yandex 'in popülerliği arttı.” (H)

" ...ilk etapta Fenerbahçe'nin Yandex'e olan katkısı oldukça fazladır. Türkiye'de \%2 pazar payına sahip Yandex, Fenerbahçe taraftarı sayesinde bu pazar payını arttıracaktır. Fenerbahçe’ye katkısı da transfer dönemlerinde ortaya çıkacaktır"'(EE)

Çalışmaya katılan Beşiktaş ve Galatasaray taraftarlarına, ana sponsorluğun Yandex ve Fenerbahçe'ye katkısı sorulduğunda, katılımcıların tamamı FenerbahçeYandex ana sponsorluk anlaşması sayesinde Yandex'in Türkiye pazarındaki farkındalığının arttığını vurgulamışlardır. Aynı zamanda katılımcılar yalnızca Fenerbahçe taraftarları özelinde değil, diğer takım taraftarları arasında da bilinirliğin ve farkındalığın arttığını ifade etmişlerdir. Katılımcılar görüşlerini şu şekilde aktarmışlardır;

“Yandex’in bilinirliği arttı, artık beş yaşındaki çocuk bile artık Yandex'i biliyor. " $(A)$

“Yandex'e bir imaj kazandırmıştır. Diğer takım taraftarları bile Yandex'i konuşuyor. Fenerbahçe taraftarı açısından Yandex sempati kazanmıştır ve aralarında gönül bağı oluşmuştur. "(SK)

"Fenerbahçe taraftarlarl Yandex'i kullanmaya başladl, bence Yandex'e sempati ve ilgi arttı" $(S)$

'Yandex'e imaj katmıştır, artık birçok kişi Yandex’i biliyor. Fenerbahçe'yi destekleyen kişiler tarafindan bir sempati de oluşmuştur. “ $(K)$

3.5. Fenerbahçe Yandex Ana Sponsorluk Anlaşması Kapsamında, Katılımcıların Fenerbahçe Yandex Tarayıcısını İndirme ve Kullanma Durumu 
Araştırmaya katılan Fenerbahçe taraftarlarına, Fenerbahçe Yandex Tarayıcını kullanma durumları sorulduğunda, katılımcıların yarısının düzenli olarak Fenerbahçe Yandex Tarayıcısını kullandığı ortaya çıkmıştır. Diğer yarısı ise tarayıcıyı indirmediklerini aktarmışlardır. Katılımcıların tarayıcıyı kullanma ve kullanmama nedenleri araştırıldığında, tarayıcıyı kullanmayan kişilerin futbola olan ilgi düzeyinin düşük ve orta düzeyde olduğu görülmüştür. Ancak, tarayıcıyı düzenli olarak kullanan kişilerin ise yüksek oranda takımlarını düzenli olarak takip ettikleri ve futbola ilgi düzeylerinin yüksek olduğu görülmüştür. Ayrıca Fenerbahçe Yandex tarayıcısını düzenli olarak kullanan taraftarların, Yandex'i ilk defa sponsorluktan sonra kullanmaya başlaması önemli bir noktadır. Katılımcılar konu hakkında görüşlerini şu şekilde belirtmişlerdir;

"Fenerbahçe Yandex Tarayıcısını bilgisayarıma ve telefonuma indirdim. Internet ile ilgili olan her işime Fenerbahçe Yandex Tarayıcısından yapıyorum"(EN)

“Fenerbahçe Yandex Tarayıcısını düzenli olarak kullanıyorum”(M)

"Fenerbahçe Yandex Tarayıcısını telefonuma, tabletime ve bilgisayarıma indirdim. Günde ortalama yetmiş arama yaplyorum " $(H)$

"Telefon ve bilgisayarıma indirdim. Başkanın da söylediği gibi günde en az on arama yapmaya çalışıyorum. ”(EE)

Çalışmaya katılan diğer takım taraftarlarına Yandex tarayıcısını kullanım durumları sorulduğunda katılımcıların tamamına yakını Yandex’i kullanmadıklarını söylemişlerdir. Sadece iki katılımcı Yandex'i sponsorluktan önce, bazen kullandıklarını ama sponsorluk sonrasında kullanmayı bıraktıklarını söylemişlerdir. Kullanmayı bırakmalarının sebebini "Yandex'in rakip takımımıza sponsor olması" olarak ifade etmişlerdir.

\subsection{Katılımcıların Fenerbahçe Yandex Tarayıcısının Kullanılması Adına Önerilerde Bulunma Durumu}

Çalışmaya katılan Fenerbahçe taraftarlarına, Fenerbahçe Yandex Tarayıcısını kullanma adına önerilerde bulunma durumu sorulduğunda, gelen yanıtlarda katılımcıların yarısının çevresine önerilerde bulunmadığı, diğer yarısının ise 
çevresini kullanmaya teşvik ettiği ortaya çıkmıştır. Katılımcıların çevrelerindeki kullanım oranları sorulduğunda, benzer bir durum göze çarpmaktadır. Katılımcıların yarısı çevrelerinde Fenerbahçe Yandex Tarayıcısının kullanılmadığını, diğer bir yarısı ise çevresindeki birçok kişinin Fenerbahçe Yandex Tarayıcısını kullandığını ifade etmişlerdir.

Çevresine önerilerde bulunmayan ve çevresinde kullanım oranı düşük kişilerin aynı zamanda Yandex tarayıcısını kullanmadığı ve futbola olan ilgi düzeylerinin düşük olduğu görülmektedir. Çevresine Fenerbahçe Yandex tarayıcısının kullanılmasını öneren ve çevrelerinde de kullanılan kişilerin Fenerbahçe Yandex tarayıcısını kullandığı ve futbola olan ilgi düzeyinin yüksek olduğu görülmektedir.

\subsection{Beşiktaş ve Galatasaray Taraftarlarının Fenerbahçe-Yandex Ana Sponsorluğu}

\section{Sonrasında Yandex Hakkındaki Görüşleri}

Araştırmaya katılan Beşiktaş ve Galatasaray taraftarlarına, Fenerbahçe ana sponsorluğu sonrasında Yandex hakkındaki görüşleri sorulduğunda; taraftarların büyük çoğunluğunun Yandex hakkındaki görüşlerinin değişmediği ortaya çıkmıştır. Ancak üç taraftarının Yandex'e karşı olumsuz bir tutum sergilediği görülmektedir. Aynı zamanda Yandex'e karşı olumsuz tutum geliştiren bu kişilerin futbola ilgi düzeylerinin yüksek olduğu görülmektedir.

\section{8. "Fenerbahçe Yandex Ana Sponsorluk Anlaşması Başarılı Buluyor musunuz, Vaat Edilen Yerlere Geleceğine İnanıyor musunuz?" Sorusuna Verilen Yanıtlar}

Çalışmaya katılan Fenerbahçe taraftarlarına ana sponsorluk anlaşmasını başarılı bulma ve vaat edilen yerlere gelme durumu sorulduğunda, katılımcıların yarısı başarılı bulduğunu ve vaat edilen yerlere geleceğini ifade etmişlerdir. Diğer yarısı ise, ana sponsorluk anlaşmasının vaat edilen yerlere gelemeyeceğini, reklamlarda bahsedilen ünlü futbolcuları alamayacaklarını düşündüklerini ifade etmişlerdir. Bu konuda bazı katılımcıların görüşleri;

"Yoğun kullanılmadı̆̆ını düşündüğüm için başarılı olmayacaktır ve söylenen futbolcular gelmeyecektir. " $(F)$ 
"Bence proje şimdiden amacına ulaştı. Birçok kişi tarayıcıyı indirdi. Bence başarılı olacaktır." (B)

"Kesinlikle başarılı olacă̆ına inanıyorum." (EN)

“Fenerbahçe-Yandex sponsorluğunu başarll buluyorum, beklenen seviyeye ulaşacağından eminim” " $(H)$

" İlk haftalarda başarılı gibiydi ama sonrasında bence başarısız oldu”(M)

Araştırmaya katılan Beşiktaş ve Galatasaray taraftarlarının tümü ana sponsorluk anlaşmasının başarılı bir anlaşma olduğunu düşünmektedir. Ancak büyük bir çoğunluğu anlaşmanın vaat edilen yerlere geleceğine inanmamaktadır. Ana sponsorluk anlaşmasından bahsedilen miktarlarda gelir elde edilemeyeceğini ve adı geçen futbolcuların alınamayacağını ifade etmişlerdir. Beşiktaş ve Galatasaray taraftarı görüşlerini şu şekilde belirtmişlerdir:

"Kesinlikle başarılı bir anlaşma ama vaat edilen yerlere gelemez, reklamlarda adı geçen futbolcuları alamazlar"(SK)

“ Başarll bir sponsorluk olabilir ama bence vaat edilen yerlere gelemez, aynı zamanda Yandex hedef kitlesini de daraltmıştır. "(A)

” Anlaşma başarılı fakat vaatler çok ütopik. Dünya starları sadece tıklama ile gelmez."(EM)

\subsection{Taraftarların Destekledikleri Takıma, Yandex'in Sponsor Olmasını İsteme Durumları}

Odak grup görüşmesine katılan Beşiktaş ve Galatasaray taraftarlarının tamam1, "Yandex'in takımınıza sponsor olmasını ister misiniz" sorusuna "isterdim" yanıtını vermişlerdir. Katılımcılar "Yandex'in tüm takımlara aynı anda sponsor olmaları durumunda çok daha başarılı bir proje olabileceğini ifade etmişlerdir." Katılımcılardan İsmail ve Semih Yandex Fenerbahçe'ye sponsor olduktan sonra Fenerbahçe ve Yandex'in özdeşleşmesinden dolayı Yandex sponsorluğuna olumsuz bakmaya başladıklarını ifade etmişlerdir. Beşiktaş ve Galatasaray taraftarı konuyla ilgili görüşlerini şu şekilde belirtmişlerdir: 
“ $\ddot{U}$ ç büyük takımada aynı anda sponsor olup rekabet duygusu oluştursaydı çok başarılı olabilirlerdi." (SK)

“Olmasını isterim fakat Fenerbahçe'ye sponsor olduktan sonra Yandex'in sponsorluğuna daha olumsuz bakmaya başladım. Yandex tüm takımlara aynı anda sponsor olsaydı daha etkili olabilirdi" (EM)

"Fenerbahçe ve Yandex kendini bütünleştirdikten sonra sponsor olmasını istemem aynı anda ya da daha önce sponsor olsaydı isterdim” (I)

“Fenerbahçe'ye sponsor olmadan önce isterdim ama şu anda Fenerbahçe ile Yandex özdeşleşti”'(S)

\subsection{Fenerbahçe-Yandex Ana Sponsorluk Anlaşması Ile İlgili Yayınlanan Reklamlar Hakkında Katılımcıların Görüşleri}

Odak grup görüşmesine katılan Fenerbahçe taraftarları, televizyonda yayınlanan Fenerbahçe-Yandex ana sponsorluğuna yönelik reklamları izleme durumlarını ve reklamlar hakkındaki görüşlerini şu şekilde ifade etmişlerdir:

“Taraftarın ilgisini çekmek için iyi bir reklam olmuştur.” (F)

“Reklamlarda verilmek istenen mesaj direkt verilmiş, Fenerbahçe’nin ünlü oyuncuları reklamda kullanıldığı için ilgi çekici olmuştur.” (O)

"Reklamlar gayet başarılı. Ünlü futbolcuların oynatılması ünlü-kulüp bă̆lantısını kurması açısından oldukça önemlidir." (B)

"Yapılan üç reklamı da izledim ve etkileyici buldum. Suarez, Ronaldo gibi futbolcuların isimlerinin geçmesi etkili olmuştur. Ayrıca Fenerbahçe Yandex Tarayıcısı kullanımını da arttırdı̆̆ını düş̈̈n̈̈yorum” (H)

"Reklamların hepsini izledim. Acun Ilıcalı'nın seslendirme yapmasi ve reklam konsepti oldukça başarılı.” (EE)

Katılımcıların ifadelerinden görüldüğü üzere reklamların taraftarlar üzerinde etkili olduğu görülmektedir. Özellikle reklamlarda ünlü futbolcuların yer alması ve Acun Ilıcalı'nın sesinin kullanılmasının taraftarlar üzerinde etkili olduğu söylenebilir. Acun Ilıcalı'nın sesinin etkili olmasında Fenerbahçeliliği ile sık sık 
gündeme gelmesi ve Türkiye'de çok tanınan bir kişi olmasından kaynaklandığ söylenebilir. Ayrıca reklamların içeriğinin öğretici olması, Yandex'in nasıl kullanıldığını ve günde kaç kelime aratılması gerektiğini vurgulaması Fenerbahçe Yandex Tarayıcısının kullanımında etkili olduğu söylenebilir.

Çalışmaya katılan Beşiktaş ve Galatasaray taraftarına reklamlar ile ilgili görüşleri sorulduğunda, katılımcıların büyük bir çoğunluğu reklamları basit bulmuşlardır. Üç katılımcı ise reklamları başarılı bulmuştur. Katılımcıların konu ile görüşleri şu şekildedir:

“Basit bir reklam olmuş” (EM)

"Reklamlar çok basit olmuş. Taraftarın gözüne çok fazla sokulmaya çalışılmıştır” (İ)

“Çok da başarılı değil. Basit bir reklam bence." (E)

"Reklamda bir hikaye akışı yok, done ve bilgilerle bir hikaye oluşturulup sunulsa daha iyi olurdu”, (K)

\subsection{Katılımcıların İnternet platformlarında (Sosyal Medya, Forumlar, Sözlükler) Fenerbahçe Yandex Tarayıcısını Kullanmaya Yönelik Çalışmalar Hakkındaki Bilgi Durumları}

Odak grup görüşmesine katılan Fenerbahçe taraftarına, internet ortamında Fenerbahçe Yandex Tarayıcısını kullanmaya yönelik yapılan çalışmalar hakkında bilgileri olup olmadıkları ve çalışmalara katılıp katılmadıkları sorulduğunda, katılımcıların birçoğu sosyal medya üzerinden paylaşımlar gördüğünü ama bu paylaşımlara destek olmadıklarını söylemişlerdir. Katılımcılardan üçü bu paylaşımlara destek olduklarını ifade etmişlerdir. Paylaşımlara destek veren üç katılımcının da futbola olan ilgi düzeyinin yüksek olduğu görülmektedir. Katılımcılar konuya ilişkin görüşlerini şöyle ifade etmişlerdir:

“ Sosyal medyada Fenerbahçe Yandex Tarayıcısını kullandırtmaya yönelik çalışmalar gördüm ama bu çalışmalara katılmadım. "(F)

“Fenerbahçe’nin resmi Twitter ve Facebook sayfası Fenerbahçe Yandex Tarayıcısını kullanmaya yönelik paylaşımlarda bulunuyor. "(O) 
“Konuyla ilgili çok fazla paylaşım görmedim”(M)

\subsection{Sponsorluk Öncesinde ve Sonrasında Katılımcıların Yandex İle İlgili Görüşleri}

Çalışmaya katılan Fenerbahçe taraftarlarına Fenerbahçe Yandex ana sponsorluk anlaşmasından önce ve sonra Yandex hakkındaki görüşleri sorulduğunda katılımcıların tamamının Yandex'e olan farkındalığının ve sempatisinin arttı̆g görülmektedir. Katılımcılardan ikisi Yandex'i daha önce duyduklarını ama marka hakkında fikre sahip olmadıklarını, diğer katılımcılar ise Yandex'e sponsorluk öncesinde olumsuz baktıklarını ama sponsorluk sonrasında olumlu yönde bir farkındalık olduğunu ve ürün/hizmetlerini kullanmaya başladıklarını aktarmışlardır. Konu ile ilgili katılımcılarından bazılarının görüşleri şu şekildedir:

"Sponsorluk öncesinde aktif kullanmiyordum fakat sponsorluk sonrasında Yandex'e olan farkındalı̆̆ım arttı ve Yandex'i kullanmaya başladım." (M)

“Yandex'e sponsorluk sonrasinda sempatim arttı”, $(O)$

"Yandex sponsor olduğunda görüşlerim olumluydu, bu olumlu görüşüm giderek arttı şu an da elimden geldiğince Yandex'te arama yapıyorum” (EN)

“Daha önce Yandex'in navigasyon uygulamasını denemiştim ama sponsorluk sonrasında Yandex'in tüm ürün ve hizmetlerini kullanmaya başladım”, $(H)$

\section{Sonuç}

Markanın hedef kitleleri arasında karşılıklı iletişimi kurup, markaya yönelik farkındalığı arttıran, güveni, sempatiyi ve olumlu imajı oluşturan halkla ilişkilerin, en fazla kullanılan uygulamalarının başında sponsorluk gelmektedir. Sponsorluk kapsamında en çok kullanılan sponsorluk türlerinden biri de spor sponsorluğudur.

Yapılan analizler sonucunda araştırmaya katılan taraftarların ağırlıklı bir kısmı, Fenerbahçe-Yandex Ana Sponsorluk anlaşmasını geleneksel bir kitle iletişim aracı olan televizyon yoluyla öğrenmişlerdir. Buradan yola çıkarak televizyon reklam ve haberlerinin haber alma sürecinde etkili bir kitle iletişim aracı olduğu söylenebilir.

Katılımcılar, Yandex'in Fenerbahçe taraftarı sayesinde geniş kitlelere ulaştığını ve ulaşabileceğini ifade etmişlerdir. Diğer takım taraftarları da, ana sponsorluk anlaşması ve televizyonda yayınlanan reklamlar aracılığıyla sadece 
Fenerbahçe taraftarına değil tüm taraftarlara yönelik bir farkındalık oluştuğunu ifade etmişlerdir. Katılımcıların tamamı ana sponsorluk anlaşmasının Fenerbahçe'ye maddi kazanç sağladığını, Yandex'e ise farkındalık kazandırdığını, aynı zamanda Fenerbahçe taraftarının Yandex'e karşı olan sempatisinin arttığını ve Türkiye pazarında payının artabileceğini ifade etmişlerdir.

Araştırmaya katılan Fenerbahçe taraftarının "Fenerbahçe-Yandex Tarayıcısı" kullanım oranlarına bakıldığında katılımcıların yarısı tarayıcıyı düzenli olarak kullandığını ifade ederken, diğer yarısı ise hiç kullanmadığını ifade etmiştir. Tarayıcıyı düzenli olarak kullanan taraftarların futbola olan ilgi düzeylerinin yüksek olması, tarayıcı kullanmayan taraftarın ise futbola olan ilgi düzeyinin düşük ve orta düzeyde olması vurgulanması gereken bir unsur olarak görülmektedir. "Fenerbahçe taraftarının futbola olan ilgi düzeyine göre, Fenerbahçe-Yandex tarayıcısını kullanım oranı değişmektedir.” hipotezi bu bulgu ile doğrulanmaktadır.

Ana sponsorluk anlaşmasının yapılmasından sonraki süreçte (Ağustos 2015) Yandex'in sayfa gösterim sayısının Türkiye'de giderek arttığı ifade edilmektedir. Yandex Türkiye sayfasının gösterim sayısı 296 milyondan (Ağustos 2015) 473 milyona (Kasım 2015) çıktığı görülmektedir ${ }^{3}$. Ana sponsorluk anlaşmasının ardından iki haftalık dönemde Fenerbahçe taraftarı yaklaşık olarak 400 bin arama

\footnotetext{
${ }^{3}$ IAB Türkiye İnternet Ölçümleme Araştırması, Türkiye'de internet kullanımını ölçmeye yönelik en kapsamlı araştırmadır. Gemius ve Ipsos konsorsiyumu tarafından yürütülen araştırma 4 bölümden oluşmaktadır.

Birinci bölümde, 12 yaş ve üstü temsili 4.000 bireyle her ay yüz yüze görüşülmekte ve aylık bazda internet penetrasyonu hesaplanmaktadır.

İkinci bölümde araştırmaya fiilen katılan sitelere yerleştirilen kodlar üzerinden, sitelerin trafik verileri gerçek zamanlı olarak toplanmaktadır.

Üçüncü bölümde 45.000 kişiyi aşkın üyesi bulunan pop-up panel aracıllğıyla, kodlu siteleri ziyaret edenlerin sosyo demografik verileri, yaşam alışkanlıkları ve sahiplik bilgileri toplanmakta ve trafik verisine entegre edilmektedir.

Çalışmanın dördüncü ve son bölümünde Yazılım Paneli (Software Panel) devreye girmekte ve bilgisayara indirilen özel bir program aracılığılla kodsuz sitelerin kullanımına ve kullanıcılarına ilişskin veri toplanmaktadır.

Araştırmanın raporları trafik verileriyle her iki panelin çıktılarının birleştirilmesi ve çevrimdışı anketten gelen veriyle ağırlıklandırılmasıyla hazırlanmakta, raporlar ESOMAR kuralları gereği kullanıcıları bir grup olarak kapsamakta ve hiçbir kullanıcının kişisel olarak tanınmasına izin vermemektedir.
}

(http://www.iabturkiye.org/top20) 
gerçekleştirmiştir. Ayrıca Yandex'in Türkiye'deki kullanım yüzdesi \%7.30'dan \%8.46'ya yükselmiştir (www.webtekno.com). Bu bulgular doğrultusunda Yandex kullanımının artışındaki nedenlerden birinin de ana sponsorluk anlaşması sonucunda Fenerbahçe taraftarı tarafından gerçekleştirilen aramalar olduğu söylenebilir.

Çalışmaya katılan Fenerbahçe taraftarının yarısı ana sponsorluk anlaşmasının vaat edilen yerlere geleceğine inanmaktadır, bu anlaşma sayesinde Fenerbahçe kulübünün büyük miktarlarda gelir elde edeceğini ve ünlü futbolcuları transfer edebileceklerini ifade etmişlerdir. Diğer Fenerbahçe taraftarları ise, bahsedilen ünlü futbolcuları transfer edemeyeceklerini ve çok büyük gelirler elde edemeyeceklerini düşünmektedir. Bu bulgu araştırmanın "Fenerbahçe taraftarı Yandex ile yapılan ana sponsorluk anlaşmasını başarılı bulmaktadır ve vaat edilenlerin gerçekleşeceğine inanmaktadır." hipotezini doğrulamaktadır.

Odak grup görüşmesine katılan Beşiktaş ve Galatasaray taraftarları, Yandex'in kendi takımlarına ana sponsor olmasını istediklerini belirtmişlerdir. Ayrıca katılımcılar, Yandex'in tüm takımlara aynı anda sponsor olması durumunda, böyle bir sponsorluğun takımlar ve taraftarlar arasında rekabete yol açacağını ve bu rekabetin de Yandex'e olumlu yönde katkıları olacağını ifade etmişlerdir.

Çalışmaya katılan Fenerbahçe taraftarları, yeni medyada Fenerbahçe Yandex uygulamasını kullanmaya yönelik yapılan çalışmaları görmediklerini ifade etmişlerdir. Ancak katılımcılardan üçü bu çalışmaları sosyal medya ve forumlarda gördüklerini ve çalışmalara destek verdiklerini vurgulamışlardır. Aynı zamanda çalışmalara destek veren üç katılımcının da futbola ilgisinin yüksek düzeyde olduğu görülmektedir.

Ana sponsorluk sonrasında çalışmaya katılan Fenerbahçe taraftarının tümünün Yandex'e olan sempatisinin ve farkındalığının arttı̆̆ görülmektedir. Sponsorluk öncesinde taraftarlar, Yandex'in ürün ve hizmetini kullanmadıklarını belirtirken, sponsorluk sonrasında ürün ve hizmetlerine ilgi duyduklarını ve kullanmaya başladıklarını belirtmişlerdir. $\mathrm{Bu}$ sonuç, araştırmanın “-Fenerbahçe taraftarının Yandex'e karşı olan sempatisi ve bilinirliği artmıştır. Yandex 
sponsorluğu Fenerbahçe taraftarı üzerinde farkındalık oluşturmuştur” hipotezini doğrulamaktadır.

Yandex ana sponsorluğun taraftar odaklı olması, taraftarın ilgisine göre sponsorluktan kazanılacak miktarın değişmesi, bu ortaklıkta taraftarı çok önemli bir konuma getirmiştir. Fenerbahçe kulübü, Fenerbahçe-Yandex tarayıcısının kullanılmasının artması adına ünlü futbolcularını kullanarak televizyon reklamları yayınlamıştır. Ayrıca Fenerbahçe kulübü sosyal medya sayfalarındaki paylaşımlar ile Fenerbahçe-Yandex tarayıcısını kullanmaya teşvik etmeye yönelik çalışmalar yapmaktadir.

\section{KAYNAKÇA}

AKYÜREK, Rüveyde (1998). Sponsorluk Planlaması. Eskişehir: Anadolu Üniversitesi Eğitim, Sağlık ve Bilimsel Araştırma Çalışmaları Vakfı Yayınları.

ALAY, Sema (2004). Spor Sponsorluğuna Tüketicinin Verdiği Reaksiyonu Belirleyen Etmenler Ve Spor Sponsorluğunun Tüketicilere Olan Etkisi, Gazi Üniversitesi Sağlık Bilimleri Enstitüsü Yayımlanmamış Doktora Tezi, Ankara.

ALEXANDER, Nicholas (2009). "Defining Brand Values Through Sponsorship". International Journal of Retail and Distribution Management, 37(4), p.346357.

BENNET, Roger (1999). “Sport Sponsorship, Spectator Recall and False Consensus. European Journal of Marketing", 33(3/4), p. 291-313.

BISCAIA, Rui ; CORREIA, Abel; ROSADO, Antonio Fernando; Ross, Stephen ve MAROCO, Joao (2013). "Sport Sponsorship: The Relationship Between Team Loyalty, Sponsorship Awareness,Attitude Toward the Sponsor, and Purchase Intentions". Journal of Sport Management, 27, p. 288-302.

BISCAIA, Rui; CORREIA, Abel; ROSS, Stephen ve ROSADO, Antonio (2014). "Sponsorship effectiveness in professional sport:an examination of recall and 
recognition among football fans". International Journal of Sports Marketing \& Sponsorship, 16 (1), p. 7-23.

CHADWICK, Simon ve THWAITES, Des (2004). "Advances in the management of sport sponsorship: fact of fiction? Evidence from English professional soccer. Journal of General Management", 30(1), p.39-60.

CHEN, Kenneth ve ZHANG, James (2011).’Examining Consumer Attributes Associated With Collegiate Athletic Facility Naming Rights Sponsorship”. Development ofa theoretical framework. Sport Management Review, 14, p.103-116.

COPELAND, Robert; Frisby, Wend ; MCCARVILLE, Ron (1996). "Understanding the Sport Sponsorship Process From A Corporate Perspective". Journal of Sport Management, 10, p.32-48.

COVELL, Dan (2008). "The Lowell Spinners and the Yankee Elimination Project: A Case Study Consideration of Linking Community Relations and Sponsorship". Sport Marketing Quarterly, 17(2), p.122-126.

ÇAVUŞOĞLU, Bora (2011). Marka Yönetimi ve Pazarlama Stratejileri. Ankara: Nobel Akademik Yayınc1lık.

ÇETIN, Cem (2014). Spor İletişimi. Ankara: Nobel Yayın.

ENGİNKAYA, Ebru (2014). "Futbol Takımlarının Sponsor Markalara İlişkin Tutum, Satın Alma Niyeti ve Takımla Özdeşleşmeleri Arasındaki İlişski”. Marmara Üniversitesi İktisadi ve İdari Bilimler Fakültesi Dergisi, 35(2), s.145-158.

ERKAL, Mustafa; BALOĞLU, Burhan; BALOĞLU, Filiz (1997). Ansiklopedik Sosyoloji Sözlüğü. İstanbul: Der Yayınları.

GRASSINGER, Gülçin Elçin (2003). Sponsorluk Sözleşmesi. Ankara: Seçkin Yayıncilik.

GROHS, Reinhard; WAGNER, Udo; VSETECKA, Sabine (2004). "Assessing the Effectiveness of Sport Sponsorships An Empirical Examination". Schmalenbach Business Review, 56, p.119-138. 
GÜÇLÜ, Mehmet (2001). “Olimpiyat Oyunları ve Spor Sponsorluğu”. Gazi Eğitim Fakültesi Dergisi, 21(3), s.223-239.

GÜMÜŞ, Sefer ve ERDEM, Birol (2014). "Spor Sponsorluklarının Tüketici Tutumuna Etkisi, Hava Yolu Müşterileri Üzerine Bir İnceleme”. International Anatolia Academic Online Journal, 2(1), s.1-25.

İFTAR, Gönül (2004). “Özel Eğitimde Fokus Grup Araştırmaları”. Ankara Üniversitesi Eğitim Bilimleri Fakültesi Özel Eğitim Dergisi, 5(1), s.1-9.

KARADEMİR, Tamer; DEVECİĞLU, Sebahattin; ÖZMADEN, Murat (2010)."Sektör Kavramları İçerisinde Bulunan Spor Sponsorluğuna Bir Bakış”. Niğde Üniversitesi Beden Eğitimi ve Spor Bilimleri Dergisi, 4(1), s.77-87.

KARAHÜSEYINOĞLU, Fatih; KIRTEPE, Abdurrahman; ALTINGÜL, Oğuzhan; GACAR, Atalay (2015).“Lisansüstü Öğrencilerin Futbol Takip Düzeyleri”. Akademik Sosyal Araştırmalar Dergisi, 3(15), s.370-377.

KAZANCI, Metin (2002). Kamuda ve Özel Kesimde Halkla İlişkiler. Ankara: Turhan Kitabevi.

KAZANCI, Metin (2007). Kamuda ve Özel Kesimde Halkla İlişkiler. Ankara: Turhan Kitapevi.

LEE, Myung Soo ; SANDLER, Dennis; SHANI, David (1997). “Attitudinal Constructs Towards Sponsorship: Scale Development Using Three Global Sporting Events”. International Marketing Review, 14(3), p.159-169.

ODABAŞI, Yavuz ve OYMAN, Mine (2006). Pazarlama İletişimi Yönetimi. İstanbul: MediaCat Kitapları.

OĞUZ, Tarkan (2005). "Popüler Kültür ve Sporun Endüstrileşme Süreci”. Anadolu Üniversitesi İletişim Bilimleri Kurgu Dergisi(21), s.195-204.

OKAY, Aydemir (1998). Halkla İlişkiler Aracı Olarak Sponsorluk. İstanbul: Epsilon Yayıncilık.

OKAY, Aydemir (2002). "Spor Sponsorluğu”. Pi Dergisi, 2(2), s.49-56. 
ÖZTÜRK, Sevgi Ayşe (1992).’Pazarlama iletişiminde gelişen bir kavram: Destekleme faaliyetleri (Sponsorluk)”. Pazarlama Dünyası, 6(34), s.18-29.

ÖZTÜRK, Sevgi Ayşe (2013). Spor Sponsorluğu: Kavram ve Özellikler, (Editör), Metin Argan. Sporda Sponsorluk, Eskişehir: Anadolu Üniversitesi.

PELTEKOĞLU, Filiz Balta (2012). Halkla İlişkiler Nedir? İstanbul: Beta Basım.

ROY, Donald ve CORNWELL, Bettina (2003). "Brand Equity's Influence on Responses to Event Sponsorships". Journal of Product \& Brand Management, 12(6), p.377-393.

SALI, Jale Balaban (2012). İletişim Araştırmalarında Nitel Yöntemler, (Editörler) Serdar Sever ve Nevzat Bilge İspir içinde, İletişim Araştırmaları, Eskişehir: Anadolu Üniversitesi Açıköğretim Fakültesi Yayını.

SANDLER, Dennis ve SHANI, David (1989). “Olympic Sponsorship vs. Ambush Marketing: Who Gets The Gold?" Journal of Advertising Research, 29(4), p.9-14.

TAŞOĞLU, Nihal Paşalı (2014). Pazarlama İletişimi. Ankara: Detay Yayıncılık.

TOSUN, Nurhan Babür (2003). Pazarlama Halkla İlişkileri ve Reklam: Bütünleşik Pazarlama İletişim Yönlü Bir Yaklaşım. İstanbul: Türkmen Kitabevi.

TOZKOPARAN, Güler ve VATANSEVER, Çiğdem (2011). "Farkl1lıkların Yönetimi: İnsan Kaynakları Yöneticilerinin Farklılık Algısı Üzerine Bir Odak Grup Çalışması”, Akdeniz İ.İ.B.F. Dergisi, 21, s.89-109.

YAĞIZ, Yağmur (2012). Bankaların Kültür ve Sanat Projeleri: Garanti Bankası Salt Projesi Örneği, İstanbul Kültür Üniversitesi Sosyal Bilimler Enstitüsü. Yayımlanmamış Yüksek Lisans Tezi, İstanbul.

YILDIRIM, Ali ve ŞİMŞEK, Hasan (2004). Sosyal Bilimlerde Nitel Araştırma Yöntemleri. Ankara: Seçkin Yayınları.

http://www.iabturkiye.org/top20 Erişim Tarihi: 03.02.2016

http://www.fenerbahce.org/detay.asp?ContentID=46233 Erişim Tarihi: 03.02.2016 
https://www.kap.gov.tr/bildirim-sorgulari/bildirim-detayi.aspx?id=462167 Erişim Tarihi: 03.02.2016

https://sirket.yandex.com.tr/general_info/about_yandex.xmlErişim Tarihi: 03.02 .2016 http://www.webtekno.com/internet/google-in-kullanim-orani-90-in-altina-indih11398.html Erişim Tarihi: 06.01.2016 